\title{
Towards Building an Early Warning Model to Predict the Financial Crises of Jordanian Islamic Banks
}

\author{
Hana' AL- Huneiti \\ Dean, College of Business \& Finance \\ The World Islamic Sciences \& Education University (WISE), Amman, Jordan \\ E-mail: hanahilal@yahoo.com \\ Yousef Abd Al-Ghani \\ Ph.D. Islamic banks, The World Islamic Sciences \& Education University (WISE) \\ E-mail: Yousef.hani86@yahoo.com
}

Received: Feb. 17, 2016

Accepted: March 5, 2016 Published: April 1, 2016

doi:10.5296/jmr.v8i2.9044

URL: http://dx.doi.org/10.5296/jmr.v8i2.9044

\begin{abstract}
This study aimed to build an early warning model to predict financial crisis at the Jordanian Islamic banks during (2000-2013). So, the study included thirteen independent variables, and four dependent variables.

Among the most important findings of the study there is no significant Effect of the economic indicators and indicators of the financial performance of the financial crisis, as measured by the real exchange rate due to growing confidence in the dinar, achievements of monetary stability reflected positively on the Jordanian economy, and the international reserves due to the central bank's policy to keep a basket of foreign currencies as reflected positively on the Jordanian economy. While total bank deposits is due to the adoption of central bank control policy and legislative prudent on the banking system, an increasing demand for Islamic banks in light of the crisis, which was reflected positively on the increased size deposits in particular. Finally, total bank reserves is due to the retention of Islamic banks with capital and high reserves, protected from exposure to any financial crisis. The most important, as recommended by the study, is that Islamic banks are advised to use these four models as an early warning system protects them from exposure to any risks arising from the financial crisis.
\end{abstract}

Keywords: Financial crises, Early warning, Islamic banks 


\section{Introduction}

The world has witnessed during the past decades many of the financial and economic crises. The most important one was the Great Depression in 1929, and the crisis of global debt with in the beginning of the eighties, then the Asian crisis during (1997-1998). Finally, the global financial crisis that emerged indicators in early 2008, which was considered as the worst since the Great Depression, according to diagnosis, studies, and analysis of the global financial crisis many specialists referred that the reasons for the result was a miscalculation in the administration, and control of the financial markets that must be corrected through more laws and provisions of the control to prevent the recurrence of such crises, or reduce the negative consequences. So, attention is needed to develop systems which leading financial indicators to provide permanent and continuous tool for guiding and warning the decision and policy makers about the possibility of exposure economic and financial crises, to take the necessary policies and procedures to reduce the crisis effect, prevent, or even avoid facing economic and financial crises.

Islamic banks are an integral part of the financial and banking system and their relations with banks and financial institutions and financial markets as well, especially in light of their growing role and significantly to the economic development, the purpose of this research is to build an early warning model to predict the financial crises for the Jordanian Islamic banks.

\section{Theoretical Framework}

\subsection{Defining Financial Crisis}

A Sharp and sudden disturbance in some economic balances, followed by a collapse in the number of financial institutions and indicators of performance and extends its effects to other sectors of the economy, followed by a severe turmoil in financial markets (stocks and bonds), then the failure or collapse of the banking system in the performance of its main functions (loans and bank deposits), followed by a deterioration in the value of the currency (confidence in the country's currency loss) (AL- Kandari, 2009).

\subsection{Types of Financial Crises}

2.2.1 Banking Crises: these crises appear when the bank faces a large and sudden increase in the demand for the withdrawal of deposits and thus a liquidity crisis occurs and if extended to other banks occur banking crisis, in the case of availability of deposits banks and refuses to play the granting of loans and for fear of not being able to meet withdrawal requests lending crisis occur (Kortell.2009).

2.2.2 Currency Crises: these crises appear when currency gets severe drop in the national currency is preceded by value or accompanied by a sharp decline in foreign reserves by monetary authorities, which will reflect on the individuals, companies, and institutions to transfer financial and monetary assets into foreign currencies to avoid the expected decline in the value of national currency, which may occur as a result of the emergence of imbalances at the macroeconomic level (AL-Janabi, 2003). 


\subsection{Defining Early Warning System}

The basic idea of the early warning system is monitor the evolution of a number of economic variables. When one of these variables deviates from its normal level beyond a certain value, this is taken as a warning signal about a possible crisis within a specific period of time. This specific period of time is called early (Jdaitawi, 2010).

\section{Previous studies}

AL-Janabi,H, This study aimed to define the concept of the financial crisis and of the monetary crisis and banking crisis suffered by many countries during the eighties and nineties, and is a sample study in selected Asian countries actually experienced a financial crisis (Indonesia, Thailand, Korea), the study relied on a set of warning indicators early to predict financial crises, most notably the change in the exchange rate, the current account deficit to GDP, domestic credit to GDP, money supply (M2) to international reserves, foreign debt to GDP, the most important finding is the need to continue analysis of macroeconomic indicators to be used as indicators of warning about the possibility of a country in financial crisis (AL-Jaabi,H,2003).

Tarawneh, A, The study aimed to develop an early warning system predicted the economic crisis in Jordan during the period (1976-2003), the study relied on a set of indicators that are used in the economic alarm system and are as follows: the real exchange rate, reserves the state of foreign currencies, the general budget, credit local, external debt relative to GDP, and the most important findings that the most important Effect of the likelihood of a crisis due to the external debt to GDP ratio in the case of the debt crisis, and the rate of reserve growth in the case of the reserves crisis and the real exchange rate growth in the case of the exchange rate crisis(Tarawneh,A,2004).

AL-O'toum, R, The study aimed to analyze the banking crises that have occurred in Jordan, and develop a framework to model scientific predicting such crises in the future, and to achieve the objectives of the study was the analysis on the 26 banks conducted factor system banking in Jordan, including 16 banks successful and long-lasting, 10 banks exposed to the crises and failed, then came out of the market or merged with other existing banks, the study used an advanced financial approach based on a set of financial soundness indicators as well as they are based on the methodology of CAMELS, the most important finding is that the failed banks showed considerable dispersion in the industry standard, compared with the successful banks, as the study also found that banks foreign better off in terms of financial soundness indicators(AL-O'toum, R,2006).

Jdaitawi, Q, This study aimed to develop an early warning of crises currency system during the period (1984-2008) is able to predict and to give early warning of the possibility of a crisis, the study relied on a range of indicators, including: degree of economic openness, trade exchange rate, exports, current account balance, the real exchange rate, inflation, employment, trade balance, foreign exchange reserves at the Central Bank, the broad money supply, the real interest rate, domestic credit, political stability, the budget deficit, GDP, and the most important findings of this study that all indicators Posted on average signals within 6 months 
and 24 months before the outbreak of the crisis, and on this basis, all of these indicators is considered the leader of the crisis indicators rather than indicators occurred by chance before the crisis (Jdaitawi, Q, 2008)

AL-Amid,A, The study aimed to examine the overall prudential indicators and the molecule to determine the extent to which the Iraqi economy to financial crises, during the period (2003 -2009), the study relied on the descriptive analytical method by tracking the progress of the College of Banking and Economic Indicators, the most important finding is the need for asylum banking institutions to macro prudential indicators being a framework that ensures the safety of the banking sector as a whole from falling into crisis(AL-Amid,A,2010).

\section{Methodology}

The global financial crisis in 2008 left many questions in all international bodies and organizations due to the nature of the outstanding negative repercussions numerous on all financial system elements of private banks and financial institutions in all their forms. The fact that Islamic banks are one of these institutions, they are worth the diligence and the hedge to avoid or deal with any crises may are exposed, and based on the above, the purpose of this study is to try to build an early warning model to predict financial crises at the Jordanian Islamic banks, based on this context, the following hypotheses are proposed:

$\mathrm{H}_{0.1}$ : No effect is statistically significant at the level of significance $(\alpha \leq 0.05)$ economic indicators and indicators of the overall financial performance of the combined cash crisis as measured by the change in the real exchange rate.

$\mathrm{H}_{0.2}$ : No effect is statistically significant at the level of significance $(\alpha \leq 0.05)$ economic indicators and indicators of the overall financial performance of the combined cash crisis as measured by the change in international reserves.

$\mathrm{H}_{0.3}$ : No effect is statistically significant at the level of significance $(\alpha \leq 0.05)$ economic indicators and indicators of the overall financial performance of the combined banking crisis in the Jordanian Islamic banks as measured by the change in total bank deposits.

$\mathrm{H}_{0.4}$ : No effect is statistically significant at the level of significance $(\alpha \leq 0.05)$ economic indicators and indicators of the overall financial performance of the combined banking crisis in the Jordanian Islamic banks as measured by the change in total bank reserves.

\subsection{Scope of the study}

The data were related to research by referring to the annual reports issued by the Central Bank of Jordan, and reports issued by the International Monetary Fund collection (IMF), and the annual reports of the study sample of Islamic banks for the period (2000-2013) the practical side will be in testing research hypotheses.

\subsection{Multivariate analysis - probit model}

Multiple regression of seventeen variables model, of which thirteen variables independent consists of a gross domestic product (GDP), inflation, money supply (M2), domestic public debt to total debt, external public debt to total debt, the current account to GDP, quick 
liquidity, return on assets, return on equity, capital adequacy, non-performing debt, resources employment, and the dependent variables are four variables which are the real exchange rate, international reserves, bank reserves, bank deposits:

Real Exchange Rate $=\beta_{0}+\beta_{1}$ GDPR $+\beta_{2}$ INFR $+\beta_{3}$ MSR $+\beta_{4}$ ELR $+\beta_{5}$ ILR $+\beta_{6}$ CRRNT + $\beta_{7}$ QUICK $+\beta_{8}$ ROA $+\beta_{9}$ ROE $+\beta_{10}$ EPS $+\beta_{11}$ CAPAD $+\beta_{12}$ NONPERF $+\beta_{13}$ EMPLOY $+\mathrm{e}_{\mathrm{i}}$.

International Reserves $=\beta_{0}+\beta_{1}$ GDPR $+\beta_{2}$ INFR $+\beta_{3}$ MSR $+\beta_{4}$ ELR $+\beta_{5}$ ILR $+\beta_{6}$ CRRNT $+\beta_{7}$ QUICK $+\beta_{8}$ ROA $+\beta_{9}$ ROE $+\beta_{10}$ EPS $+\beta_{11}$ CAPAD $+\beta_{12}$ NONPERF $+\beta_{13}$ EMPLOY + $\mathrm{e}_{\mathrm{i}}$.

Bank Deposits $=\beta_{\mathrm{i}}+\beta_{1}$ GDPR $+\beta_{2}$ INFR $+\beta_{3}$ MSR $+\beta_{4}$ ELR $+\beta_{5}$ ILR $+\beta_{6}$ CRRNT $+\beta_{7}$ QUICK $+\beta_{8}$ ROA $+\beta_{9}$ ROE $+\beta_{10}$ EPS $+\beta_{11}$ CAPAD $+\beta_{12}$ NONPERF $+\beta_{13}$ EMPLOY $+e_{i}$.

Bank Reserves $=\beta_{\mathrm{i}}+\beta_{1}$ GDPR $+\beta_{2}$ INFR $+\beta_{3}$ MSR $+\beta_{4}$ ELR $+\beta_{5}$ ILR $+\beta_{6}$ CRRNT $+\beta_{7}$ $\mathrm{QUICK}+\beta_{8} \mathrm{ROA}+\beta_{9} \mathrm{ROE}+\beta_{10}$ EPS $+\beta_{11} \mathrm{CAPAD}+\beta_{12}$ NONPERF $+\beta_{13}$ EMPLOY $+\mathrm{e}_{i}$.

Where:

\begin{tabular}{|c|c|}
\hline Abbreviation & The term \\
\hline$\beta \mathrm{i}$ & Regression coefficients (i=0,1,.....13) \\
\hline GDPR & Gross Domestic Product \\
\hline INFR & Inflation \\
\hline MSR & Money Supply (M2) \\
\hline ELR & Domestic Public Debt To Total Debt \\
\hline ILR & External Public Debt To Total Debt \\
\hline CRRNT & Current Account To GDP \\
\hline QUICK & Quick Liquidity \\
\hline ROA & Return On Assets \\
\hline ROE & Return On Equity \\
\hline EPS & Earnings Per Share \\
\hline CAPAD & Capital Adequacy \\
\hline NONPERF & Non Performing Debt \\
\hline EMPLOY & Resources employment \\
\hline ei & Error term. \\
\hline
\end{tabular}

Source: Authors

\section{Analysis}

Statistical analysis of the dependent variables and independent variables was performed through an initial testing of the following: multicollinearity tests and test indication Pearson correlation, and autocorrelation test (Autocorrelation) in order to get rid of the autocorrelation problem, then Durbin-Watson test, and analysis of multiple linear regression simple tests in order to test hypotheses and access to the results. 


\section{Macrothink}

Journal of Management Research

ISSN 1941-899X 2016, Vol. 8, No. 2

\subsection{Appropriate model test}

\subsubsection{Multicollinearity tests}

Pearson correlation coefficients were used for the detection of the problem of multiple linear correlations between the variables of the study; the following table shows the correlations to the variables of the independent study matrix.

Table 1. correlation matrix between macroeconomic indicators

\begin{tabular}{|c|c|c|c|c|c|c|}
\hline Variable & $\begin{array}{c}\text { Gross } \\
\text { Domestic } \\
\text { Product }\end{array}$ & Inflation & $\begin{array}{c}\text { Money } \\
\text { Supply } \\
\text { (M2) }\end{array}$ & $\begin{array}{c}\text { Domestic } \\
\text { Public Debt } \\
\text { to Total Debt }\end{array}$ & $\begin{array}{c}\text { External } \\
\text { Public Debt } \\
\text { to Total Debt }\end{array}$ & $\begin{array}{c}\text { Current } \\
\text { Account to } \\
\text { GDP }\end{array}$ \\
\hline $\begin{array}{c}\text { Gross Domestic } \\
\text { Product }\end{array}$ & 1 & \multicolumn{3}{|l|}{} \\
\hline $\begin{array}{c}\text { Inflation } \\
\text { Money Supply } \\
\text { (M2) }\end{array}$ & $0.456^{* *}$ & 1 & 1 & & \\
\hline $\begin{array}{c}\text { Domestic Public } \\
\text { Debt to Total Debt }\end{array}$ & $0.497^{* *}$ & $0.436^{*}$ & $0.507^{* *}$ & & \\
\hline $\begin{array}{c}\text { External Public } \\
\text { Debt to Total Debt }\end{array}$ & -0.343 & -0.292 & -0.275 & $-0.727^{* *}$ & & 1 \\
\hline $\begin{array}{c}\text { Current Account to } \\
\text { GDP }\end{array}$ & $0.386^{*}$ & -0.069 & $0.464^{* *}$ & $-0.153^{* *}$ & & 0.037 \\
\hline
\end{tabular}

$(* *)$ statistically significant at $(\alpha \leq 0.01)(*)$ statistically significant at $(\alpha \leq 0.05)$.

Source: Authors

We can see from the table above that the highest correlation between the independent variables is $(0.727)$ between the two variables (the rate of change in the size of domestic public debt / total public debt) and (the rate of change in the size of the external public debt / total public debt) while the coefficient values between the other independent variables were less than that, and this shows the lack of multiple linear correlation phenomenon between the independent variables, where the link that connects to the higher of $(0.80)$ an indication of the existence of multiple high linear correlation problem. So, we can say that the sample did not face this problem.

To confirm the previous result Variance Inflation Factor (VIF) was calculated and the results were as follows: 


\section{Macrothink}

Journal of Management Research

ISSN 1941-899X

2016, Vol. 8, No. 2

Table 2. Multi-link test between macroeconomic indicators Results

\begin{tabular}{|l|l|}
\hline Variable & Variance Inflation Factor(VIF) \\
\hline Gross Domestic Product & 2.126 \\
\hline Inflation & 1.791 \\
\hline Money Supply (M2) & 2.53 \\
\hline Domestic Public Debt To Total Debt & 5.548 \\
\hline External Public Debt To Total Debt & 3.713 \\
\hline Current Account To GDP & 1.354 \\
\hline
\end{tabular}

Source: Authors

We can see from table (2), that VIF values were all greater than 1 and less than 10, which indicates the lack of multiple linear correlation problems between the variables of the study.

Table 3. Correlation matrix of the financial performance indicators

\begin{tabular}{|c|c|c|c|c|c|c|c|}
\hline Variable & $\begin{array}{l}\text { Quick } \\
\text { Liquidity }\end{array}$ & $\begin{array}{c}\text { Return } \\
\text { On } \\
\text { Assets }\end{array}$ & $\begin{array}{l}\text { Return On } \\
\text { Equity }\end{array}$ & $\begin{array}{c}\text { Earning Per } \\
\text { Share }\end{array}$ & $\begin{array}{c}\text { Capital } \\
\text { Adequacy }\end{array}$ & $\begin{array}{c}\text { Non } \\
\text { Performing } \\
\text { Debt }\end{array}$ & $\begin{array}{l}\text { Resource } \\
\text { Utilization }\end{array}$ \\
\hline $\begin{array}{c}\text { Quick } \\
\text { Liquidity }\end{array}$ & 1 & & & & & & \\
\hline $\begin{array}{l}\text { Return On } \\
\text { Assets }\end{array}$ & -0.027 & 1 & & & & & \\
\hline $\begin{array}{c}\text { Return On } \\
\text { Equity }\end{array}$ & $-0.118^{* *}$ & $0.812^{* *}$ & 1 & & & & \\
\hline $\begin{array}{c}\text { Earning Per } \\
\text { Share }\end{array}$ & 0.028 & $0.755^{\star *}$ & 0.76 & 1 & & & \\
\hline $\begin{array}{c}\text { Capital } \\
\text { Adequacy }\end{array}$ & 0.167 & 0.163 & -0.341 & $-0.379^{*}$ & 1 & & \\
\hline $\begin{array}{c}\text { Non } \\
\text { Performing } \\
\text { Debt }\end{array}$ & -0.074 & $-0.440^{*}$ & -0.211 & -0.047 & $0.432^{*}$ & 1 & \\
\hline $\begin{array}{l}\text { Resource } \\
\text { Utilization }\end{array}$ & -0.159 & -0.138 & -0.229 & -0.318 & 0.234 & -0.03 & 1 \\
\hline
\end{tabular}

$(* *)$ Statistically significant at $(\alpha \leq 0.01)(*)$ statistically significant at $(\alpha \leq 0.05)$.

Source: Authors

We can notice from table (3) that the highest correlation between the independent variables is 
(0.812) which is between the two variables (ROA) and (ROE) while the correlation coefficient values between other independent variables were less than that, and this shows a lack of the phenomenon of multiple linear correlation between the independent variables, where is the link that connects to the higher of $(0.80)$ an indication of the existence of multiple high linear correlation problem. So, we can say that the sample did not face this problem. To confirm the previous result Variance Inflation Factor (VIF) was calculated and the results were as follows:

Table 4. Multi-link test between the financial performance indicators results

\begin{tabular}{|c|c|}
\hline Variable & Variance Inflation Factor(VIF) \\
\hline Quick Liquidity & 1.962 \\
\hline Return On Assets & 8.393 \\
\hline Return On Equity & 5.8 \\
\hline Earnings Per Share & 4.601 \\
\hline Capital Adequacy & 3.738 \\
\hline Non Performing Debt & 3.1 \\
\hline Resource Utilization & 1.327 \\
\hline
\end{tabular}

Source: Authors

We can observe from table (4) that VIF values were all greater than 1 and less than 10, which indicates the lack of multiple linear correlation problems between the variables of the study.

\subsubsection{Autocorrelation test}

Data is free from the autocorrelation problem conditions, which is known as correlation between the presence of random error terms in the regression model, resulting in a bias in the value of the estimated parameters, and thus the weakness of the model's ability to predict. Also, to be sure about that conduct of Durbin-Watson Test, and support this test to compare the statistical value of DW's spreadsheet for a sample size of (n) and the number of variables (k) with the result of the calculated DW, where there are two values for statistical DW (dl) minor and $(\mathrm{du})$ great value are rejected values, the existence of autocorrelation problem if the value is greater than the calculated DW, the results were as in the following table:

Table 5. Autocorrelation test

\begin{tabular}{|l|l|l|l|l|}
\hline Hypothesis & The value of (D-W) calculated & dl & du & Result \\
\hline $\mathrm{H}_{0.1}$ & 2.817 & 0.445 & 2.805 & No autocorrelation \\
\hline $\mathrm{H}_{0.2}$ & 2.992 & 0.445 & 2.805 & No autocorrelation \\
\hline $\mathrm{H}_{0.3}$ & 2.808 & 0.445 & 2.805 & No autocorrelation \\
\hline $\mathrm{H}_{0.4}$ & 2.899 & 0.445 & 2.805 & No autocorrelation \\
\hline
\end{tabular}


Source: Authors

\subsection{Testing Study’s hypotheses}

Hypotheses of the study were tested by multiple linear regression analysis, and the results were as follows:

The first hypothesis $\left(\mathrm{H}_{0.1}\right)$ : There is no significant Effect between economic and overall financial performance indicators on one side, and the cash crisis on the other side at the level of significance $(\alpha \leq 0.05)$.

Table 6. Testing the Effect of macroeconomic and financial performance indicators on the combined results of the monetary crisis, as measured by the change in the real exchange rate.

\begin{tabular}{|c|c|c|c|c|c|c|c|c|c|}
\hline \multirow[b]{2}{*}{$\begin{array}{c}\text { Dependent } \\
\text { variable }\end{array}$} & \multirow{2}{*}{$\begin{array}{c}\mathbf{R} \\
\text { Correlation } \\
\text { coefficient }\end{array}$} & \multirow{2}{*}{$\begin{array}{c}\mathbf{R}^{2} \\
\text { Coefficient of } \\
\text { determination }\end{array}$} & \multirow[b]{2}{*}{ Calculated } & \multirow{2}{*}{$\begin{array}{c}\text { Sig } F^{*} \\
\text { Level of } \\
\text { significance }\end{array}$} & \multicolumn{5}{|c|}{ Regression coefficients } \\
\hline & & & & & Statement & B & $\begin{array}{c}\text { Standard } \\
\text { error }\end{array}$ & $\begin{array}{c}\text { T } \\
\text { Calculated }\end{array}$ & $\begin{array}{c}\text { Sig } \mathrm{t}^{*} \\
\text { Level of } \\
\text { significance }\end{array}$ \\
\hline \multirow{14}{*}{$\begin{array}{l}\text { Change in } \\
\text { the real } \\
\text { exchange } \\
\text { rate } \\
\text { (EXCHR) }\end{array}$} & \multirow{14}{*}{0.606} & \multirow{14}{*}{0.367} & \multirow{14}{*}{3.038} & \multirow{14}{*}{0.069} & GDPR & 0.214 & 0.288 & 0.745 & 0.469 \\
\hline & & & & & INFR & 0.002 & 0.002 & 0.817 & 0.428 \\
\hline & & & & & MSR & 0.01 & 0.214 & 0.045 & 0.965 \\
\hline & & & & & ELR & -0.109 & 0.083 & -1.317 & 0.209 \\
\hline & & & & & ILR & -0.202 & 0.099 & -2.045 & 0.052 \\
\hline & & & & & CRRNT & -0.002 & 0.001 & -2.468 & 0.027 \\
\hline & & & & & QUICK & 0.058 & 0.036 & 1.612 & 0.129 \\
\hline & & & & & ROA & 1.051 & 2.646 & 0.397 & 0.697 \\
\hline & & & & & ROE & 0.21 & 0.499 & 0.421 & 0.681 \\
\hline & & & & & EPS & -17.386 & 20.501 & -0.848 & 0.411 \\
\hline & & & & & CAPAD & 0.096 & 0.066 & 1.453 & 0.168 \\
\hline & & & & & NONPERF & 0.708 & 0.277 & 2.559 & 0.023 \\
\hline & & & & & EMPLOY & 0.175 & 0.126 & 1.388 & 0.187 \\
\hline & & & & & $\mathrm{C}$ & -12.19 & 5.343 & -2.281 & 0.039 \\
\hline
\end{tabular}

(*) The effect is statistically significant at $(\alpha \leq 0.05)$

Source: Authors

The results from table (6) are that the effect is statistically significant, where calculated $\mathrm{F}$ value is (3.038), and the level of significance ( $\operatorname{Sig} F=0.069$ ) which is greater than 0.05, while the correlation coefficient $(\mathrm{R}=0.606)$ refers to the relationship between the variables, in addition to the value of the coefficient of determination was $\left(\mathrm{R}^{2}=0.367\right)$, pointing out that (36.7\%) of the variation in (the change in the real exchange rate) can be explained by the variation in (macroeconomic indicators and indicators of financial performance) combined, with all other variables constant.

The regression coefficients table showed that the value of $B$ when (the rate of change in GDP) has reached (0.214) and the value of $(\mathrm{t})$ is $(0.745)$, and the level of significance $(\mathrm{Sig}=0.469)$, suggesting that the effect was not significant for this variable. when the value of $\mathrm{B}$ (the rate of 
change in inflation) amounted to (0.002), and that has a value of $(t)$ is $(0.817)$, and the level of significance $(\mathrm{Sig}=0.428)$, suggesting that the effect of this variable is not significant. As the value of $B$ when (the rate of change in the money supply) has reached (0.010) and that has a value of $(\mathrm{t})$ is $(0.045)$, and the level of significance ( $\mathrm{Sig}=0.965)$, suggesting that the effect of this variable is not significant. The value of $B$ when the variable (the rate of change in the external debt) amounted to (-0.109) and that has a value of $(t)$ is $(-1.317)$, and the level of significance ( $\mathrm{Sig}=0.209)$, suggesting that the effect of this variable is not significant. The value of $B$ when the variable (the rate of change in domestic debt) (-0.202) and has a value of $(\mathrm{t})$ is $(-2.045)$, and the level of significance ( $\mathrm{Sig}=0.054)$, suggesting that the effect of this variable is not significant. The value of $B$ when the variable (the rate of change in the current account) amounted to (-0.002) and has a value of $(t)$ is $(-2.468)$, and the level of significance $(\mathrm{Sig}=0.027)$, suggesting that the effect of this is a significant variable.

The regression coefficients table showed that when the value of $\mathrm{B}$ (quick) liquidity ratio stood at (0.058) and that has a value of ( $\mathrm{t}$ ) is (1.612), and the level of significance ( $\mathrm{Sig}=$ 0.129 ), suggesting that the effect of this variable is not significant. And that when the value of B (return on assets) amounted to (1.051), and that has a value of $(\mathrm{t})$ is $(0.397)$, and the level of significance $(\mathrm{Sig}=0.697)$, suggesting that the effect of this variable is not significant. As they were when the value of B (ROE) stood at $(0.210)$ and that has a value of $(t)$ is $(0.421)$, and the level of significance ( $\mathrm{Sig}=0.681)$, suggesting that the effect of this variable is not significant. The value of the variable B (EPS) amounted to (-17.386) and that has a value of ( $t)$ is $(-0.848)$, and the level of significance ( $\mathrm{Sig}=0.411)$, suggesting that the effect of this variable is not significant. The value of the variable B (capital adequacy ratio) is (0.096) and has a value of $(\mathrm{t})$ is $(1.453)$, and the level of significance ( $\mathrm{Sig}=0.168)$, suggesting that the effect of this variable is not significant. The value of $B$ when the variable (debt non-performing ratio) stood at (0.708) The value of $(\mathrm{t})$ is (2.559), and the level of significance $(\mathrm{Sig}=0.023)$, suggesting that the Effect of the moral of this variable, and the value of $B$ when the variable (employment rate Resources) has reached $(0.175)$ and has a value of $(\mathrm{t})$ is (1.388), and the level of significance ( $\mathrm{Sig}=0.187)$, suggesting that the effect of this variable is not significant.

Accordingly, the first regression equation will be written as:

EXCHR $=-12.190+214 *$ GDPR $+0.002 *$ INFR $+0.010 *$ MSR $-0.109 *$ ELR $-0.202 *$ ILR $-0.002 * \mathrm{CRRNT}+0.058 * \mathrm{QUICK}+1.051 * \mathrm{ROA}+0.210 * \mathrm{ROE}-17.386 * \mathrm{EPS}-0.096 *$ $\mathrm{CAPAD}+0.708 * \mathrm{NONPERF}+0.15 *$ EMPLOY $+\mathrm{e}_{\mathrm{i}}$.

The Second hypothesis $\left(\mathrm{H}_{0.2}\right)$ : There is no significant Effect between economic and overall financial performance indicators on one side, and the cash crisis on the monetary crisis, as measured by the change in international reserves on the other side at the level of significance $(\alpha \leq 0.05)$. 
Table 7. Testing the Effect of economic indicators and indicators of the financial performance as combined on monetary crisis, as measured by the change in the gross international reserves.

\begin{tabular}{|c|c|c|c|c|c|c|c|c|c|}
\hline \multirow[b]{2}{*}{$\begin{array}{c}\text { Dependent } \\
\text { variable }\end{array}$} & \multirow{2}{*}{$\begin{array}{c}\text { R } \\
\text { Correlation } \\
\text { coefficient }\end{array}$} & \multirow{2}{*}{$\begin{array}{c}\mathbf{R}^{2} \\
\text { Coefficient of } \\
\text { determination }\end{array}$} & \multirow{2}{*}{$\begin{array}{c}\text { F } \\
\text { Calculated }\end{array}$} & \multirow{2}{*}{$\begin{array}{c}\text { Sig F* } \\
\text { Level of } \\
\text { significance }\end{array}$} & \multicolumn{5}{|c|}{ Regression coefficients } \\
\hline & & & & & Statement & B & $\begin{array}{c}\text { Standard } \\
\text { error }\end{array}$ & $\begin{array}{c}\text { T } \\
\text { Calculated }\end{array}$ & $\begin{array}{c}\text { Sig } \mathrm{t}^{*} \\
\text { Level of } \\
\text { significance }\end{array}$ \\
\hline \multirow{14}{*}{$\begin{array}{c}\text { Total } \\
\text { change in } \\
\text { international } \\
\text { reserves } \\
\text { (INTDEP) }\end{array}$} & \multirow{14}{*}{0.631} & \multirow{14}{*}{0.399} & \multirow{14}{*}{2.347} & \multirow{14}{*}{0.06} & GDPR & -1.218 & 3.139 & -0.388 & 0.704 \\
\hline & & & & & INFR & 0.024 & 0.022 & 1.097 & 0.291 \\
\hline & & & & & MSR & 4.444 & 1.843 & 2.411 & 0.03 \\
\hline & & & & & ELR & 2.285 & 0.673 & 3.396 & 0.004 \\
\hline & & & & & ILR & 0.694 & 0.739 & 0.939 & 0.364 \\
\hline & & & & & CRRNT & 0.021 & 0.004 & 4.963 & 0.000 \\
\hline & & & & & QUICK & -0.108 & 0.203 & -0.533 & 0.602 \\
\hline & & & & & ROA & -0.594 & 8.681 & -0.068 & 0.946 \\
\hline & & & & & ROE & -1.186 & 1.296 & -0.915 & 0.376 \\
\hline & & & & & EPS & 56.702 & 59.848 & 0.947 & 0.36 \\
\hline & & & & & CAPAD & 0.029 & 0.18 & 0.161 & 0.875 \\
\hline & & & & & NONPERF & -0.283 & 0.78 & -0.363 & 0.722 \\
\hline & & & & & EMPLOY & 0.111 & 0.422 & 0.262 & 0.797 \\
\hline & & & & & $\mathrm{C}$ & -8.694 & 29.43 & -0.295 & 0.772 \\
\hline
\end{tabular}

$\left.{ }^{*}\right)$ The effect is statistically significant at $(\alpha \leq 0.05)$

Source: Authors

The results of table (7) that the Effect of macroeconomic indicators and indicators of financial performance on the dependent variable (the change in the gross international reserves) are the effect is statistically significant, where the F value calculated is (2.347), and the level of significance ( $\mathrm{Sig} F=0.060$ ) which is greater than 0.05 , while the correlation coefficient $(\mathrm{R}=0.631)$ refers to the relationship between the variables, in addition to the value of the coefficient of determination it was $\left(\mathrm{R}^{2}=0.399\right)$, pointing out that $(39.9 \%)$ of the variation in the (change in gross international reserves) can be explained by the variation in (macroeconomic indicators and indicators of financial performance) combined, with all other variables constant.

The regression coefficients table showed that the value of $B$ when (the rate of change in GDP) has reached $(-1.218)$ and that has a value of $(\mathrm{t})$ is $(-0.388)$, and the level of significance is $(\mathrm{Sig}=0.704)$, suggesting that the effect of this variable is not significant. And that when the value of B (the rate of change in inflation) amounted to (0.024), and that has a value of (t) is (1.097), and the level of significance ( $\mathrm{Sig}=0.291)$, suggesting that the effect of this variable is not significant. As the value of $\mathrm{B}$ when (the rate of change in the money supply) has reached (4.444) and that has a value of ( $\mathrm{t}$ ) is (2.411), and the level of significance (Sig = 0.030 ), suggesting that the effect of this significant variable. The value of $B$ when the variable (the rate of change in the external debt) amounted to (2.285), and that has a value of $(\mathrm{t})$ is (3.396), and the level of significance is $(\mathrm{Sig}=0.030)$, suggesting that the significant 
Effect of this variable. The value of B when the variable (the rate of change in domestic debt) is (0.694) and the value of (t) is (0.939), and the level of significance is ( $\mathrm{Sig}=0.364$ ), indicating that the Effect of this variable is not significant. The value of $\mathrm{B}$ when the variable (the rate of change in the current account) amounted to $(0.021)$ and has a value of $(t)$ is (4.063), and the level of significance is ( $\mathrm{Sig}=0.000)$, suggesting that the effect of this is a significant variable.

Table (7) the regression coefficients showed that when the value of B quick liquidity ratio has reached (-0.108) and that has a value of $(\mathrm{t})$ is $(-0.533)$, and the level of significance is (Sig = 0.602 ), suggesting that the effect of this variable is not significant. In addition, when the value of B (return on assets) amounted to $(-0.594)$ and that has a value of $(t)$ is $(-0.533)$, with the level of significance is ( $\mathrm{Sig}=0.602)$, suggesting that the effect of this variable is not significant. As they were when the value of B (ROE) stood at (-1.186) and that has a value of (t) is $(-0.915)$, the level of significance is ( $\mathrm{Sig}=0.376)$, suggesting that the effect of this variable is not significant. The value of the variable B (EPS) amounted to (56.702) and that has a value of $(\mathrm{t})$ is $(0.947)$, and the level of significance is (Sig=0.360), suggesting that the effect of this variable is not significant. The value of the variable B (capital adequacy ratio) $(0.029)$ has a value of $(\mathrm{t})$ is $(0.161)$, and the level of significance is ( $\mathrm{Sig}=0.875)$, suggesting that the effect of this variable is not significant. The value of $\mathrm{B}$ when the variable (debt non-performing ratio) amounted (-0.283) The value of (t) is (-0.363), and the level of significance is ( $\mathrm{Sig}=0.722)$, suggesting that the effect of this variable is not significant, and the value of $B$ for ratio of employment of resources amounted to (0.111) and has a value of ( $t)$ is $(0.262)$, and the level of significance ( $\mathrm{Sig}=0.797)$, suggesting that the effect of this variable is not significant.

Accordingly, the Second regression equation will be written as:

$$
\begin{aligned}
& \text { TDEPOSIT }=-8.694-1.218 * \text { GDPR }+0.024 * \text { INFR }+4.444 * \text { MSR }+2.285 * \text { ELR }+ \\
& 0.694 * \text { ILR }+0.021 * \text { CRRNT-0.108* QUICK }-0.594 * \text { ROA- } 1.186 * \text { ROE }+56.702 * \text { EPS } \\
& +0.029 * \text { CAPAD }-0.283 * \text { NONPERF }+0.111 * \text { EMPLOY }+\mathrm{e}_{i} .
\end{aligned}
$$

The third hypothesis $\left(\mathrm{H}_{0.3}\right)$ : There is no significant Effect between economic and overall financial performance indicators on one side, and banking crisis in the Jordanian Islamic banks as measured by the change in total bank deposits on the other side at the level of significance $(\alpha \leq 0.05)$. 
Table 8. Testing the Effect of economic indicators and indicators of financial performance as measured by the combined results on banking crisis change in the total bank deposits.

\begin{tabular}{|c|c|c|c|c|c|c|c|c|c|}
\hline \multirow[b]{2}{*}{$\begin{array}{c}\text { Dependent } \\
\text { variable }\end{array}$} & \multirow{2}{*}{$\begin{array}{c}\mathbf{R} \\
\text { Correlation } \\
\text { coefficient }\end{array}$} & \multirow{2}{*}{\begin{tabular}{|c}
$\mathbf{R}^{2}$ \\
Coefficient of \\
determination
\end{tabular}} & \multirow{2}{*}{$\begin{array}{c}\text { F } \\
\text { Calculated }\end{array}$} & \multirow{2}{*}{$\begin{array}{c}\text { Sig } F^{*} \\
\text { Level of } \\
\text { significance }\end{array}$} & \multicolumn{5}{|c|}{ Regression coefficients } \\
\hline & & & & & Statement & B & $\begin{array}{c}\text { Standard } \\
\text { error }\end{array}$ & $\begin{array}{c}\mathbf{T} \\
\text { Calculated }\end{array}$ & $\begin{array}{c}\text { Sig t* } \\
\text { Level of } \\
\text { significance }\end{array}$ \\
\hline \multirow{14}{*}{$\begin{array}{l}\text { The change in } \\
\text { the total bank } \\
\text { deposits } \\
\text { (TDEPOSIT) }\end{array}$} & \multirow{14}{*}{0.588} & \multirow{14}{*}{0.346} & \multirow{14}{*}{0.57} & \multirow{14}{*}{0.84} & GDPR & -0.396 & 3.274 & -0.121 & 0.906 \\
\hline & & & & & INFR & -0.005 & 0.027 & -0.191 & 0.852 \\
\hline & & & & & MSR & 3.491 & 2.437 & 1.433 & 0.174 \\
\hline & & & & & ELR & -0.338 & 0.941 & -0.359 & 0.725 \\
\hline & & & & & ILR & -0.146 & 1.126 & -0.129 & 0.899 \\
\hline & & & & & CRRNT & 0.011 & 0.009 & 1.165 & 0.263 \\
\hline & & & & & QUICK & -0.127 & 0.406 & -0.312 & 0.76 \\
\hline & & & & & ROA & -7.544 & 30.108 & -0.251 & 0.806 \\
\hline & & & & & ROE & -1.655 & 5.682 & -0.291 & 0.775 \\
\hline & & & & & EPS & 95.519 & 233.256 & 0.41 & 0.688 \\
\hline & & & & & CAPAD & 0.251 & 0.752 & 0.335 & 0.743 \\
\hline & & & & & NONPERF & -2.224 & 3.146 & -0.707 & 0.491 \\
\hline & & & & & EMPLOY & 0.988 & 1.435 & 0.688 & 0.503 \\
\hline & & & & & C & -19.386 & 60.792 & -0.319 & 0.755 \\
\hline
\end{tabular}

$\left.{ }^{*}\right)$ The effect is statistically significant at $(\alpha \leq 0.05)$.

Source: Authors.

The results of table (8) presents that the Effect of macroeconomic indicators and indicators of financial performance on the dependent variable (the change in the total bank deposits) the effect is statistically significant, where the calculated $F$ value is $(0.570)$, and the level of significance is ( $\operatorname{Sig} F=0.840$ ) which is greater than 0.05 , while the correlation coefficient ( $R$ $=0.588$ ) refers to the relationship between the variables, in addition to the value of the coefficient of determination it was $\left(\mathrm{R}^{2}=0.346\right)$, pointing out that $34.6 \%$ of the variation in the (change in total bank deposits) can be explained by the variation in macroeconomic indicators and indicators of financial performance are combined together, with all other variables constant.

The regression coefficients table (8) showed that the value of B when (the rate of change in GDP) has reached (-0.396) and that has a value of $(t)$ is $(-0.121)$, and the level of significance is $(\mathrm{Sig}=0.906)$, suggesting that the effect of this variable is not significant. And when the value of $B$ (the rate of change in inflation) has reached (-0.005) and that has a value of ( $t)$ is $(-0.191)$, and the level of significance is $(\mathrm{Sig}=0.852)$, suggesting that the effect of this variable is not significant. As the value of B when (the rate of change in the money supply) has reached (3.491) and that has a value of (t) is (1.433), and the level of significance is (Sig $=0.174)$, suggesting that the effect of this variable is not significant. The value of $B$ when the rate of change in the external debt amounted (-0.338) and that has a value of $(t)$ is $(-0.359)$, and the level of significance is $(\mathrm{Sig}=0.725)$, suggesting that the effect of this variable is not significant. The value of $\mathrm{B}$ when the rate of change in domestic debt is $(-0.146)$ and has a 
value of $(\mathrm{t})$ is $(-0.129)$, and the level of significance is ( $\mathrm{Sig}=0.899)$, suggesting that the effect of this variable is not significant. The value of $\mathrm{B}$ for the rate of change in the current account amounted to (0.011) and has a value of $(\mathrm{t})$ is (1.165), and the level of significance is $(\mathrm{Sig}=0.263)$, suggesting that the effect of this variable is not significant.

The regression coefficients table showed that when the value of $\mathrm{B}$ for quick liquidity ratio has reached (-0.127) and that has a value of $(\mathrm{t})$ is $(-0.312)$, and the level of significance is (Sig = $0.760)$, suggesting that the effect of this variable is not significant. And that when the value of B for return on assets amounted to $(-7.544)$ and that has a value of $(t)$ is $(-0.251)$, and the level of significance is ( $\mathrm{Sig}=0.806)$, suggesting that the effect of this variable is not significant. As when the value of $\mathrm{B}(\mathrm{ROE})$ stood at $(-1.655)$ and that has a value of $(\mathrm{t})$ is $(-0.291)$, and the level of significance is $(\mathrm{Sig}=0.775)$, suggesting that the effect of this variable is not significant. The value of the variable B (EPS) amounted to (95.519) and that has a value of $(t)$ is $(0.410)$, and the level of significance is $(\mathrm{Sig}=0.688)$, suggesting that the effect of this variable is not significant. The value of the variable B (capital adequacy ratio) is (0.251) and has a value of $(\mathrm{t})$ is $(0.335)$, and the level of significance is ( $\mathrm{Sig}=0.743)$, suggesting that the effect of this variable is not significant. The value of $B$ (debt non-performing ratio) amounted (-2.224) The value of (t) is (-0.707), and the level of significance is ( $\mathrm{Sig}=0.491)$, suggesting that the effect of this variable is not significant, and the value of $\mathrm{B}$ (ratio of employment of resources) has reached (.988) and has a value of (t) is (0.668), and the level of significance is $(\mathrm{Sig}=0.503)$, suggesting that the effect of this variable is not significant.

Accordingly, the third regression equation will be written as:

TDEPOSIT $=-19.386-0.396 *$ GDPR $-0.005 *$ INFR + 3.491* MSR -0.338*ELR $-0.146 *$ $\mathrm{ILR}+0.011 * \mathrm{CRRNT}-0.127 * \mathrm{QUICK}-7.544 * \mathrm{ROA}-1.655 * \mathrm{ROE}+95.519 * \mathrm{EPS}+$ $0.251 *$ CAPAD $-2.224 *$ NONPERF $+0.988 *$ EMPLOY $+\mathrm{e}_{\mathrm{i}}$.

The Fourth hypothesis $\left(\mathrm{H}_{0.4}\right)$ : There is no significant Effect between economic and overall financial performance indicators on one side, and banking crisis in the Jordanian Islamic banks as measured by the change in total bank reserves on the other side at the level of significance $(\alpha \leq 0.05)$. 
Table 9. Testing the Effect of economic indicators and indicators of financial performance as measured by the combined results on the banking crisis as the change in total bank reserves.

\begin{tabular}{|c|c|c|c|c|c|c|c|c|c|}
\hline \multirow[b]{2}{*}{$\begin{array}{c}\text { Dependent } \\
\text { variable }\end{array}$} & \multirow{2}{*}{\begin{tabular}{c|c}
$\mathbf{R}$ \\
Correlation \\
coefficient
\end{tabular}} & \multirow{2}{*}{$\begin{array}{c}\mathbf{R}^{2} \\
\text { Coefficient of } \\
\text { determination }\end{array}$} & \multirow{2}{*}{$\begin{array}{c}\text { F } \\
\text { Calculated }\end{array}$} & \multirow{2}{*}{$\begin{array}{c}\text { Sig F* } \\
\text { Level of } \\
\text { significance }\end{array}$} & \multicolumn{5}{|c|}{ Regression coefficients } \\
\hline & & & & & Statement & B & $\begin{array}{c}\text { Standard } \\
\text { error }\end{array}$ & $\begin{array}{c}\mathbf{T} \\
\text { Calculated }\end{array}$ & $\begin{array}{c}\text { Sig t* } \\
\text { Level of } \\
\text { significance }\end{array}$ \\
\hline \multirow{14}{*}{$\begin{array}{l}\text { The change in } \\
\text { total bank } \\
\text { reserves } \\
\text { (BANKSERV) }\end{array}$} & \multirow{14}{*}{0.649} & \multirow{14}{*}{0.421} & \multirow{14}{*}{0.783} & \multirow{14}{*}{0.667} & GDPR & 10.739 & 6.303 & 1.704 & 0.111 \\
\hline & & & & & INFR & -0.035 & 0.051 & -0.688 & 0.503 \\
\hline & & & & & MSR & 0.42 & 4.691 & 0.09 & 0.93 \\
\hline & & & & & ELR & -0.712 & 1.812 & -0.393 & 0.7 \\
\hline & & & & & ILR & -1.503 & 2.168 & -0.693 & 0.5 \\
\hline & & & & & CRRNT & -0.003 & 0.018 & -0.192 & 0.851 \\
\hline & & & & & QUICK & -0.184 & 0.781 & -0.235 & 0.817 \\
\hline & & & & & ROA & -27.757 & 57.961 & -0.479 & 0.639 \\
\hline & & & & & $\mathrm{ROE}$ & -0.934 & 10.938 & -0.085 & 0.933 \\
\hline & & & & & EPS & 270.552 & 449.042 & 0.603 & 0.557 \\
\hline & & & & & CAPAD & 2.432 & 1.447 & 1.68 & 0.115 \\
\hline & & & & & NONPERF & 2.327 & 6.057 & 0.384 & 0.707 \\
\hline & & & & & EMPLOY & 2.806 & 2.763 & 1.016 & 0.327 \\
\hline & & & & & $\mathrm{C}$ & -148.488 & 117.031 & -1.269 & 0.225 \\
\hline
\end{tabular}

(*) The effect is statistically significant at $(\alpha \leq 0.05)$

Source: Authors

The results of table (9) presents the Effect of macroeconomic indicators and indicators of financial performance on the dependent variable (the change in the total bank reserves) the effect is statistically significant, where the calculated $\mathrm{F}$ value is $(0.783)$, and the level of significance is ( $\operatorname{Sig} F=0.667$ ) which is greater than 0.05 , while the correlation coefficient is $(\mathrm{R}=0.649)$ refers to the relationship between the variables, in addition to the value of the coefficient of determination it was $\left(\mathrm{R}^{2}=0.421\right)$, pointing out that $(42.1 \%)$ of the variation in the (change in total bank reserves) can be explained by the variation in (macroeconomic indicators and indicators of financial performance) together, with all other variables constant.

The regression coefficients table showed that the value of B when (the rate of change in GDP) has reached (10.739) and the value of $(\mathrm{t})$ is (1.704), and the level of significance ( $\mathrm{Sig}=0.111$ ), suggesting that the effect was not significant with this variable, and when the value of $B$ (the rate of change in inflation) has reached (-0.035) and that has a value of $(t)$ is $(-0.688)$, and the level of significance ( $\mathrm{Sig}=0.503$ ), suggesting that the effect of this variable is not significant. As the value of B (the rate of change in the money supply) has reached (0.420) and that has a value of $(\mathrm{t})$ is $(0.090)$, and the level of significance $(\mathrm{Sig}=0.930)$, suggesting that the effect of this variable is not significant. The value of $\mathrm{B}$ when the variable (the rate of change in the external debt) amounted to $(-0.712)$ and that has a value of $(t)$ is $(-0.393)$, and the level of significance ( $\mathrm{Sig}=0.700)$, suggesting that the effect of this variable is not significant. The value of $B$ when the variable (the rate of change in domestic debt) is $(-1.503)$ and has a value 
of $(t)$ is $(-0.693)$, and the level of significance ( $\mathrm{Sig}=0.500)$, suggesting that the effect of this variable is not significant. The value of $\mathrm{B}$ when the variable (the rate of change in the current account) amounted to (-0.003) and has a value of ( $t)$ is (-0.192), and the level of significance $(\mathrm{Sig}=0.851)$, suggesting that the effect of this variable is not significant.

The regression coefficients table showed that when the value of B (quick) liquidity ratio has reached (-0.184) and that has a value of $(\mathrm{t})$ is $(-0.235)$, and the level of significance (Sig = $0.817)$, suggesting that the effect of this variable is not significant. Also, when the value of B (return on assets) amounted to (-27.757) and that has a value of (t) is $(-0.479)$, and the level of significance $(\mathrm{Sig}=0.639)$, suggesting that the effect of this variable is not significant. As they were when the value of B (ROE) stood at (-0.934) and that has a value of ( $t)$ is $(-0.085)$, and the level of significance ( $\mathrm{Sig}=0.933)$, suggesting that the effect of this variable is not significant. The value of the variable B (EPS) reached (270.552) and has a value of ( $t$ ) is $(0.603)$, and the level of significance ( $\mathrm{Sig}=0.557)$, suggesting that the effect of this variable is not significant. The value of the variable B (capital adequacy ratio) is (2.432) and has a value of $(\mathrm{t})$ is $(1.680)$, and the level of significance $(\mathrm{Sig}=0.115)$, suggesting that the effect of this variable is not significant. The value of B when the variable (debt non-performing ratio) stood at (2.327) The value of $(\mathrm{t})$ is $(0.384)$, and the level of significance ( $\mathrm{Sig}=0.707$ ), suggesting that the effect of this variable is not significant, and the value of $B$ when the variable (the employment of resources rate) amounted to (2.806) and has a value of ( $t$ ) is (1.016), and the level of significance is ( $\mathrm{Sig}=0.327$ ), suggesting that the effect of this variable is not significant.

Accordingly, the fourth regression equation will be written as:

ANKSERV $=-148.488+10.739 *$ GDPR $-0.035 *$ INFR $+0.420 *$ MSR $-0.712 *$ ELR $-1.503 * \mathrm{ILR}-0.003 * \mathrm{CRRNT}-0.184 *$ QUICK $-27.757 * \mathrm{ROA}-0.934 * \mathrm{ROE}+270.552 *$ $\mathrm{EPS}+2.432 * \mathrm{CAPAD}+2.327 * \mathrm{NONPERF}+2.806 * \mathrm{EMPLOY}+\mathrm{e}_{\mathrm{i}}$

\section{Conclusions and Recommendations}

\subsection{Conclusions}

The current study found the following results:

- The study found no significant effect between macroeconomic indicators and indicators of financial performance are combined on cash crisis as measured by the change in the real exchange rate, which is considered a good indicator of the lack of exposure of the Jordanian economy monetary crisis due to the growing confidence in the dinar and achievements of monetary stability, which reflected positively on Jordan's economy, and in the opinion of the study is considered as a good model for predicting financial crises, and can be used for Islamic.

- The study found no significant effect between macroeconomic indicators and indicators of financial performance are combined on cash crisis as measured by the change in international reserves, which is a good indicator of the lack of exposure of the Jordanian economy monetary crisis due to the central bank's policy to keep a basket of foreign 
currencies as reflected positively on the economy of Jordan, and in the opinion of the study it is a good model to predict the financial crisis and banks can rely on it.

- The study found the lack of a significant effect between macroeconomic indicators and indicators of financial performance are combined on cash crisis as measured by the change in the total bank deposits, which is a good indicator of the lack of exposure of Jordanian Islamic banks. Banking crisis due to the adoption of central bank control policy and legislative prudent on the banking system, and increasing demand for Islamic banks in light of the crisis, which was reflected positively on increasing the size of its deposits in particular, and in the opinion of the study is a good model to predict the financial crisis, and banks can rely on it.

It turns out that the study and the lack of significant effect between macroeconomic indicators and indicators of financial performance are combined on cash crisis as measured by the change in total bank reserves, which is a good indicator of the lack of exposure of Jordanian Islamic banks. Banking crisis due to the retention of Islamic banks with capital and high reserves are protected from exposure to any financial crisis, and in the opinion of the study is a good model to predict the financial crisis and banks can rely on the Jordanian Islamic banks.

\subsection{Recommendations}

The study recommends that the Islamic banks take four models that have been reached in this research to get to the construction of an early warning system are protected from exposure to any dangers arising from the financial crisis.

\section{References}

Al-Janabi, H. (2003). Financial crises: the concept and its indicators and predictability in selected countries. Damascus University Journal of economic and legal sciences, 1(19), 281. http://www.damascusuniversity.edu.sy/mag/law/index.php

AL-O toum, R.(2006). Building a Model of an Early Warning System To Predict Banking Crises, Ph.D. Degree, Amman Arab University, Amman, Jordan.

AL-Amid, A.(2010). Macro prudential indicators and the possibility of early to predict crises (Empirical Study - the case of Iraq), Central Bank of Iraq, Publications.

Central Bank of Jordan. Annual Reports. (2000-2013).

Islamic International Arab Bank. Annual Reports. (2000-2013).

Jdaitawi, Q. (2008). Developing an early Warning System for Currency Crises: The Case of Jordan (1984-2008). Ph.D. Degree, University of Jordan, Amman, Jordan.

Jordan Islamic Bank. Annual Reports. (2000-2013).

Kortell, U,. \& Rezzig, K. (2009). Financial Crisis: the concept, its causes and its impact on the Arab countries. Journal of Baghdad College of Economic Sciences, 1(20), 7. 
International Monetary Fund (IMF): http://www.imf.org 2016, Vol. 8, No. 2

Tarawneh, A. (2004). Developing an Early Warning System for Predicting Economic Crises in Jordan, Master. Degree, University of Jordan, Amman, Jordan. 